\title{
The Health Status and Demographics of a Conflicting Country: The Sudan Experience
}

\author{
Miracle Ayomikun Adesina 1,2,3,4,5*
}

\author{
${ }^{1}$ Slum and Rural Health Initiative Research with Purpose Academy, NIGERIA \\ ${ }^{2}$ Cephas Health Research Initiative Inc, Ibadan, NIGERIA \\ ${ }^{3}$ Mental and Oral Health Development Organization, Kebbi State, NIGERIA \\ ${ }^{4}$ Universal Care for Africa Foundation, St. Loius, USA \\ ${ }^{5}$ Department of Physiotherapy, University of Ibadan, Ibadan, NIGERIA \\ *Corresponding Author: miracleadesina5@gmail.com
}

Citation: Adesina, M. A. (2020). The Health Status and Demographics of a Conflicting Country: The Sudan Experience. European Journal of Environment and Public Health, 4(1), em0032. https://doi.org/10.29333/ejeph/5933

\section{ARTICLE INFO}

Received: 17 Jul. 2019

Revised: 02 Sep. 2019

Accepted: 02 Sep. 2019

\begin{abstract}
The Republic of Sudan is a country located in the Northeastern region of Africa. It has a very diverse culture with about 597 ethnic groups communicating in 400 different languages and dialects. Sudan is the third-largest country in Africa and the sixteenth largest in the world. This country is blessed with numerous mineral resources such as asbestos, chromite, copper, gold, iron, lead, mica, nickel, petroleum, silver, uranium, zinc and many more. However, Sudan is not a peaceful nation. The government of Sudan has been engaged in military warfare against the Sudan Revolutionary Front since 2011. There are widespread human rights violations and religious persecutions. There are allegations that Sudan is a safe haven for terrorist. This study therefore gives an overview of the health status and demographics of the populace inhabiting this conflicting nation. In discussing the health status of the Sudan population, the data on number of the different types of health care facilities and major equipment in Sudan were presented. Also data on maternal and child health, malaria, HIV/AIDS, yellow fever, nodding diseases, noncommunicable disease mental health and dental health were presented. The demographics section displayed the population, population distribution and statistics, religion distribution and many more of the Sudan populace. Author appeals that the statistics and data presented be used in attending to the health needs of the populace of Sudan.
\end{abstract}

Keywords: health, demographics, health indicators, Sudan, conflict

\section{INTRODUCTION}

The Republic of Sudan (which differs from South Sudan officially known as the Republic of South Sudan) is a country located in the Northeastern region of Africa. It lies between latitudes $8^{\circ}$ and $23^{\circ} \mathrm{N}$. Sudan has a total area of $1,861,484$ square kilometres (718,722 square miles) (Wikipedia, 2019a). The total nominal gross domestic product (GDP) for Sudan in 2018 was $\$ 138.090$ billion and total GDP (PPP; Purchasing Power Parity) was $\$ 197.825$ billion (International Monetary Fund, 2017). Sudan has a very rich ancient history which can be traced back to the Pharaonic period (c 2500 BC) (Encylopaedia Britannica, 2019).

There are numerous United Nations agents operating in Sudan. These include the World Food Program, the United Nations Industrial Development Organizations (UNIDO), the United Nations Mine Service (UNMAS), the World Bank, the International Organization for Migration (IOM) among others (Canadian International Development Agency, 2013;
International Organization for Migration, 2012). Sudan has a very diverse culture with about 597 ethnic groups communicating in 400 different languages and dialects.

Sudan is the third-largest country in Africa and the sixteenth largest in the world (Country Studies, n.d.). The highest point in this country is the Deriba Caldera which lies at 3,042 $\mathrm{m}$ or $9,980 \mathrm{ft}$. Sudan has a number of major rivers such as the Blue Nile River, the White Nile River, etc. This country is blessed with numerous mineral resources such as asbestos, chromite, copper, gold, iron, lead, mica, nickel, petroleum, silver, uranium, zinc and many more (Embassy of the Republic of Sudan in London, 2005).

However, Sudan is not a peaceful nation. This nation has been involved in numerous wars, civil unrest, coup de'tat, etc. Examples include the coup of 1718, the Battle of Omdurman, the Second Sudanese Civil war, the Madhist War, 1971 Sudanese coup d'etat, 1989 coup d'etat, the 2003 war in Darfur, etc. (Encylopaedia Britannica, 2019; Wikipedia, 2019a). Human Rights is frequently been breached in Sudan. Reporters 
without Borders in 2018 ranked Sudan 174 in terms of freedom of press (Reporters without Borders, n.d.).

A 2013 UNICEF report establish that about 88\% of women in Sudan had undergone female genital mutilation (Costello, 2015). Another report shows that about 2 million Sudanese have died due to famine and civil unrest since 1983 (Reliefweb, 1998). Stoning is a legal punishment in Sudan and several people have died from stoning. Flogging is also a legal punishment. It is reported that between 2009 and 2014 many people were sentenced to 40-100 lashes (Wikipedia, 2019a). A UNICEF report in 2008 showed that there were about 6,000 child soldiers in Sudan (Wikipedia, 2008). There are a number of disputed areas and zones of conflicts in Sudan. These include Heglig, the Abyei Area, South Kurdufan, Blue Nile, Hala'ib Triangle, and Bir Tawail (Wikipedia, 2019a).

The government of Sudan has been engaged in military warfare against the Sudan Revolutionary Front since 2011. There are widespread human rights violations and religious persecutions. There are allegations that Sudan is a safe haven for terrorist (Wikipedia. Sudan, 2019). There are also a number of militias operating in this country, the Sudan Revolutionary Front, the Sudan People's Liberation Army, Justice and Equality Movement (JEM), etc. (Encylopaedia Britannica, 2019). This study therefore gives an overview of the health status and demographics of the populace inhabiting this conflicting nation. The statistics and data presented in this study would be helpful in attending to the health needs of the Sudanese population. The statistics presented would be useful to the numerous United Nations agencies operating in Sudan. The data and statistics presented in this study, if properly used, would lead to improvement in the wellbeing and quality of life of the Sudanese populace.

\section{HEALTH STATUS OF THE SUDANESE POPULATION}

The World Health Organization (WHO) in a 2014 report presented that there were 4,088 health posts and 1,398 health centres in Sudan. All these facilities are owned by the government. Sudan had 242 district hospitals, 256 provincial hospital, and 13 regional hospitals (World Health Organization, 2014). All the district and regional hospitals are owned by the government but all the provincial hospitals are owned by the private sector. There were 12 Magnetic Resonance Imaging device, 21 Computerized Tomography Scanner, 5 nuclear medicine device, 20 mammography, 3 linear accelerators, 4 telecobalt unit and 7 radiotherapy device in all the hospitals (private and public; health post, health centre, district, provincial and regional hospital) in Sudan based on a 2014 WHO report (World Health Organization, 2014).

The Sudan Household Survey in 2010 showed that about $26.8 \%$ of the children within age 5 to 59 months had diarrhea and $18.7 \%$ were suspected to have pneumonia (Wikipedia. Health in Sudan, 2019b). An estimated $12.6 \%$ and $15.7 \%$ of children in Sudan under age 5 suffer from severe wasting and stunting respectively (Revolvy, n.d.). The under-five mortality rate as of 2008 was 89 deaths per 1000 live births. This is about
$30 \%$ lower than the average for Africa but its 51\% higher than the global average. Also, infant mortality rate as of 2008 was put at 59 infant deaths per 1000 live births. It is noteworthy that about $65 \%$ of infant mortality occurs before the age of one and $33 \%$ during the neonatal period (first 30 days after birth) (Revolvy, n.d.; UNICEF, 2008; WHO, 2015).

In the year 2010 alone 1.6 million new cases of malaria were reported and about 23 persons in every 100,000 population died from malaria (World Health Organization, 2010). The annual incidence of tuberculosis based on a 2010 data was 119 persons per 100,000 populations (World Health Organization, 2010). The prevalence of HIV/AIDS as of 2011 was $0.4 \%$. There were an estimated 260,000 persons living with HIV and 12,000 HIV related deaths annually (UNAIDS, 2011). However, a 2018 estimate puts the HIV/AIDS prevalence at $0.2 \%$ and further states than 51,000 adults and children are living with HIV (UNAIDS, 2018).

There was an outbreak of yellow fever in 2012 which affected five states resulting in 847 suspected cases and 171 deaths (WHO, 2019). Sudan has its unique diseases called the nodding diseases. This disease is a fatal one which results in mental and physical disability. It only affects young children and is restricted to a small region in southern Sudan (Lacey, 2003).

It is reported that one in three pregnant women in Sudan have complications during pregnancy and one in two women have complications during labour and up to six weeks after delivery (Gubbins and De walque, n.d.). It is estimated that $50 \%$ of female deaths in Sudan occur during pregnancy, delivery or two months after delivery. An estimated $73 \%$ of pregnant Sudanese women reported having attended at least one antenatal checkup between 2008 and 2010 (Gubbins and De walque, n.d.). However, only $14 \%$ reported having obtained the full antenatal package which includes four antenatal care visits, two doses of tetanus toxoid vaccine, blood screen for anemia, urine screen for protein and assessment of blood pressure. In the year 2010 , about $75 \%$ of births occurred at home. This can be attributed to the fact that $75 \%$ of women reside in rural areas (Gubbins and De walque, n.d.).

Non-communicable diseases accounted for $52 \%$ of all deaths in Sudan $(282,000)$ in 2016. Breaking it down proportionally $28 \%$ of the deaths was attributed to cardiovascular diseases, $6 \%$, cancers, $3 \%$ chronic respiratory diseases, $2 \%$ diabetes, $12 \%$ other NCDs, $35 \%$, communicable, maternal, perinatal and nutritional conditions, and $13 \%$ injuries (WHO, 2018).

According to a 2011 WHO report, there were 0.06 psychiatrists per 100,000 populations; 8.17 medical doctors per 100,000 populations, 0.48 psychologists per 100,000 populations and 0.10 mental health nurses per 100,000 populations (World Health Organization, 2011). Also, there were 16 mental health outpatient facilities in Sudan making up 0.037 facilities per 100,000 populations. Sudan had 2 mental hospitals, 180 beds in mental hospitals, 387 psychiatric beds in the general hospitals, according to the WHO 2011 report (World Health Organization, 2011).

There were about 3.06 physicians per 1,000 populations as of 2014. The hospital bed density was 0.8 beds per 1,000 populations as of 2012 (The World Fact Book-Central 
Intelligence Agency, 2019). There were about 772 dentists practicing in Sudan as of 2008. The rate of malformation of the cleft lip and palate was 0.9 per 1000 in Sudan. About $44 \%$ of the population studied had a malformation of the cleft lip and the cleft palate, $30 \%$ cleft palate only and $16 \%$ cleft lip only (Malmo University, n.d.).

\section{DEMOGRAPHICS OF SUDAN}

Sudan has an estimated population size of $37,345,935$ according to a 2018 estimate. Individuals within age 0 to 14 years make up $38.68 \%$ of the total population (7,335,613 males and $7,111,552$ females). Those within age 15 to 24 years make up $21.04 \%$ of Sudan's total population $(4,033,787$ males and $3,823,098$ females). The bulk of the working class (25-54 years) forms $32.77 \%$ of the total population. This age group comprises 5,943906 males and 6293291 females (Index Mudi, 2018).

Individuals within age 55 to 64 years make up $4.24 \%$ of Sudan's total population (824,577 males and 760,014 males). The geriatric age group (65 years and above) form $3.27 \%$ of the population of Sudan. This age group is made up of 655,795 males and 563,672 females. The bulk of Sudan's populations are young children aged 0 to 14 years (38.68\%) (The World Fact Book-Central Intelligence Agency, 2019).

Sudan has a total dependency ratio of 81.6, youth dependency ratio of 75.4, elderly dependency ratio of 6.3 and potential support ratio of 15.9 according to The World Fact Book-Central Intelligence Agency. The total median age for any Sudanese is 19.9 years, 19.7 years for males and 20.1 years for females. Sudan's population growth rate is $1.64 \%$ and the birth rate is estimated at 27.9 births/1,000 population. The death rate is 7.3 deaths per a thousand populations while the net migration rate is -4.1 migrants per a thousand populations. The birth rate is quite higher than the death rate but there is a higher emigration rate (Index Mudi, 2018).

The total life expectancy from birth is 64.4 years, 62.3 years for males and 66.7 years for females. The total literacy rate among individuals aged 5 and above is $75.9 \%, 83.3 \%$ for males and $68.6 \%$ for females (The World fact book-Central intelligence Agency, 2019). The total school life expectancy is 7 years, same for both males and females. The education expenditure based on the percent of the GDP dedicated to education in 2009 is about 2.2\% (The World Fact Book-Central Intelligence Agency, 2019).

Sudan has 597 groups that speak over 400 different languages and dialects. The largest ethnic group is the Sudanese Arabs who are mostly Muslims (International Monetary Fund, 2017). They mostly speak Sudanese Arabic. There are about 70 languages native to Sudan. The Sudanese Arabic is the most widely spoken language in the country. Majority of Sudan population (over 97\%) are Muslims. There are two Islamic sects, the Sufi and the Salafi (Central Intelligence Agency, 2019).

\section{CONCLUSION}

Sudan is the third largest nation in Africa and is blessed with numerous mineral resources. Sadly this nation is not peaceful. There's presently military warfare against different militias. Conflict is known to affect the health status of the populace inhabiting the area affected. This article presented the health status and demographics of Sudan. This would be very helpful in attending to the health needs of the Sudanese populace.

\section{REFERENCES}

Canadian International Development Agency. (2013). Sudan and South Sudan. Available at: https://web.archive.org/ web/20130528183621/http://www.acdi-cida.gc.ca/acdicida/ACDI-CIDA.nsf/eng/JUD-217124359-NT2

Central Intelligence Agency. (2019). Sudan. Available at: https://www.cia.gov/-library/publications/the-worldfactbook/geos/print_su.html

Costello, S. (2015). Female genital mutilation/cutting: risk management and strategies for social workers and health care professionals. Risk Mang Healthc Policy, 8, 225-233. https://doi.org/10.2147/RMHP.S62091

Country Studies. (n.d.). Language. Available at: http://countrystudies.us/sudan/36.htm

Embassy of the Republic of Sudan in London. (2005). Geography of Sudan. Available at: https://web.archive.org/web/20050930235450/http:/www .sudan-embassy.co.uk/infobook/geograph.php

Encylopaedia Britannica. (2019). Sudan. Available at: https://www.britannica.com/place/Sudan

Gubbins, P. and De Walque, D. (n.d.). Maternal \& Child health in Sudan. Available at: http://paulgubbins.com/ projects/sudan/SudanHealth_Full.pdf

Index Mudi. (2018). Sudan Demographics Profile 2018. Available at: https://www.indexmundi.com/sudan/

International Monetary Fund. (2017). Sudan. Available at: https://www.imf.org/external/pubs/ft/weo/2017/01/weoda ta/weorept.aspx?pr.x=64\&pr.y=7\&sy=2017\&ey=2019\&scs $\mathrm{m}=1$ \&ssd $=1$ \&sort $=$ country $\& \mathrm{ds}=. \& \mathrm{br}=1 \& \mathrm{c}=732 \& \mathrm{~s}=\mathrm{NGDP}$ D\%2CNGDPDPC\%2CPPPGDP\%2CPPPPC \&grp=0 \&a=

International Organization for Migration. (2012). Sudan. Available at: https://web.archive.org/web/ 20120310183842/http://www.iom.int/jahia/Jahia/activities /africa-and-middle-east/east-africa/sudan/cache/offonce/

Lacey, M. (2003). Nodding disease: mystery of southern Sudan. Lancet Neuro, 2(12), 714. https://doi.org/10.1016/S14744422(03)00599-4

Malmo University. (n.d.). Oral Health Database-Sudan. Available at: https://www.mah.se/CAPP/Country-OralHealth-Profiles/EMRO/Sudan/Oral-Diseases/Periodontaldisease----------/ 
Reliefweb. (1998). 1.9 million dead from Sudan's Civil war; More than 70,000 deaths in 1998 Report estimates. Available at: https://reliefweb.int/report/sudan/19million-dead-sudans-civil-war-more-70000-deaths-1998report-estimates

Reporters without Borders. (n.d.). Sudan. Available at: https://rsf.org/en/sudan

Revolvy. (n.d.). Health in Sudan. Available at: https://www.revolvy.com/page/Health-in-Sudan

The World Fact Book-Central Intelligence Agency. (n.d.). Sudan. Available at: https://www.cia.gov/library/ publications/the-world-factbook/geos/su.html

UNAIDS. (2011). UNAIDS report on the global AIDS epidemic 2011. Available at: http://aidsinfo.unaids.org/

UNAIDS. (2018). Sudan. Available at: http://www.unaids.org/ en/regionscountries/countries/sudan

UNICEF. (2008). Country Profile Maternal, Newborn \% Child Survival. Available at: https://www.google.com/search? client=firefox-b-d \&q=Sudan\%27s+under-

five+mortality+rate+as+of+2008+is+89+deaths +per+1000+ live+births
UNICEF. (2008). UNICEF Humanitarian Action Report 2008. Available at: https://www.unicef.org/har08/files/ HAR_MidYearReview_2008_full_report.pdf

WHO. (2018). Noncommunicable Diseases (NCD) Country Profiles-2018: Sudan. Available at: https://www.who.int/ $\mathrm{nmh} /$ countries/sdn_en.pdf?ua=1

WHO. (2019). Yellow fever in Sudan. Available at: https://www.who.int/csr/don/2012_11_13/en/

Wikipedia. (2019a). Sudan. Available at: https://en.wikipedia.org/wiki/Sudan

Wikipedia. (2019b). Health in Sudan. Available at: https://en.wikipedia.org/wiki/Health_in_Sudan

World Health Organization. (2011). Mental Health Atlas, 2011Sudan. Available at: https://www.who.int/mental_health/ evidence/atlas/profiles/sdn_mh_profile.pdf?ua =1 1 \&ua $=1$

World Health Organization. (2014). Essential health technologies-Sudan. Available at: https://www.who.int/ medical_devices/countries/sdn.pdf?ua=1

World Health Organization. (2015). Sudan: WHO statistical profile. Available at: https://www.who.int/gho/countries/ sdn.pdf?ua=1 